\title{
Oral foreign body granuloma to soft tissue fillers. Report of two cases and review of the literature
}

\author{
Paris Tamiolakis ${ }^{1}$, Evangelia Piperi ${ }^{2}$, Panagiotis Christopoulos ${ }^{3}$, Alexandra Sklavounou-Andrikopoulou ${ }^{4}$
}

${ }^{1}$ Postgraduate Student, Department of Oral Medicine and Oral Pathology, School of Dentistry, National and Kapodistrian University of Athens, Greece

${ }^{2}$ Assistant Professor, Department of Oral Medicine and Oral Pathology, School of Dentistry, National and Kapodistrian University of Athens, Greece

${ }^{3}$ Assistant Professor, Department of Oral and Maxillofacial Surgery, School of Dentistry, National and Kapodistrian University of Athens, Greece

${ }^{4}$ Professor, Head of Department of Oral Medicine and Oral Pathology, School of Dentistry, National and Kapodistrian University of Athens, Greece

Correspondence:

41 Amyclon Street Lamprini

11142, Athens, Greece

ptamiolakis@hotmail.com

Tamiolakis P, Piperi E, Christopoulos P, Sklavounou-Andrikopoulou A. Oral foreign body granuloma to soft tissue fillers. Report of two cases and review of the literature. J Clin Exp Dent. 2018;10(2):e177-84. http://www.medicinaoral.com/odo/volumenes/v10i2/jcedv10i2p177.pdf

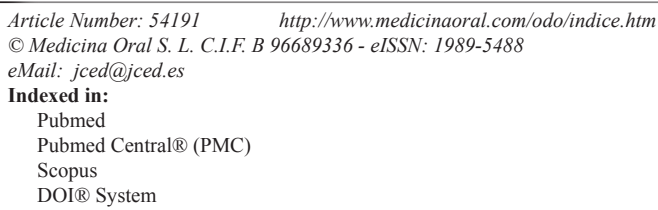

\begin{abstract}
The increasing demand for cosmetic procedures in the orofacial area nowadays, results in a growing number of complications attributable to soft tissue fillers, including the development of foreign body granuloma. The purpose of this study is to present two additional cases of oral foreign body granulomas caused by liquid silicone and hyaluronic acid respectively and review the pertinent literature regarding the demographics, the clinical appearance, the histopathology and the treatment of these lesions.
\end{abstract}

Key words: Oral foreign body granuloma, hyaluronic acid, silicone, soft tissue filler.

\section{Introduction}

Cosmetic procedures are considered a modern "weapon" against aging, a normal process that has been treated as a disease through time, mostly in the Western civilization. Nowadays, in an attempt to prevent esthetic changes as a result of aging, the use of injectable soft tissue fillers (STFs) is increasingly observed $(1,2)$.

STFs are easy to handle and cause minimal side effects (3), hence, they are used in a wide range of aesthetic procedures, ranging from cheek and chin augmentation, nose reshaping and lip enhancement to hand rejuvenation (4). Despite the increased demand, a soft tissue material that would ensure long term aesthetic results along with low complication rate and low cost is not yet available in the market (2). Additionally, while only a few STFs have been approved by the Food and Drug Administration (FDA) (5) in the United States of America, a number of non-approved fillers, such as liquid silicone, 
are still in use to date either by trained physicians or, by unlicensed practitioners $(6,7)$.

According to their biodegradability, STFs are classified by FDA into: absorbable (collagen, hyaluronic acid, calcium hydroxyapatite and poly-L-lactic acid) and non-absorbable (Polymethylmethacrylate (PMMA)) (5). Another classification is based on their duration and include temporary (absorbable), permanent (non-absorbable) and semi - permanent fillers (8). In the latter category a combination of both absorbable and non-absorbable STFs is used, with the temporary component acting not only to produce an immediate effect but also as a carrier, until the fibrotic reaction induced by the permanent filler takes place (9). The choice of the appropriate soft tissue filler (STF) to be injected depends not only on the desired outcome and the area to be treated but on the preference and the experience of the physician as well (10). Usually permanent fillers cause complications; however, both clinicians and pathologists are faced with a growing number of side effects that may arise after injection of any type of $\operatorname{STF}(9)$. The time of occurrence and the type of complication vary among different fillers(2).The combination of different types of fillers injected simultaneously in the same area does not seem to be related to increased risk of complications (13). However when they do occur, it is more likely to be more severe and chronic compared to the use of a single filler (2). STFs complications may be either immediate, of early onset or delayed $(4,7,8)$ (Table 1). Among the delayed STFs complications, foreign body granuloma (FBG) formation is the most common histologic pattern (4) with a clinical incidence between $0.02-2.8 \%(8)$.

The purpose of this study is to present two cases of oral FBG to STFs and review the pertinent literature.

\section{Case Reports}

Case 1

An 80-year-old, non-smoker, female patient presented to the outpatient Clinic of the Department of Oral Medi- cine and Oral Pathology, School of Dentistry, National and Kapodistrian University of Athens, Greece for evaluation of an asymptomatic, exophytic nodule located on the lower lip. The patient had first noticed the lesion 4 months ago and since then it has been invariable. Her medical history was unremarkable and the last blood tests where within normal limits. On clinical examination, a well - circumscribed, penduculated, painless soft nodule was noted on the left side of the lower lip (Fig. 1). The lesion was covered by normal mucosa and

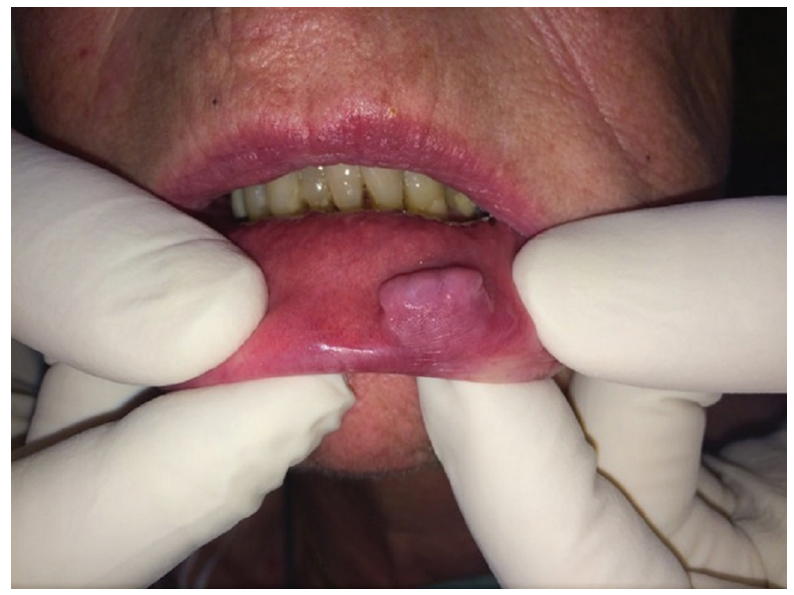

Fig. 1: Exophytic nodule on the lower lip in patient 1.

measured approximately $1.5 \times 1 \mathrm{~cm}$. The remaining oral mucosa was normal. With a provisional diagnosis of a mucocele, the lesion was excised under local anesthesia and sent for histopathological examination.

Microscopic examination of 5-mm-thick, formalin-fixed, paraffin-embedded tissue sections stained with hematoxylin-eosin revealed numerous, variably sized clear cystic spaces, some of which contained amorphous eosinophilic material, interspersed in a fibrous connec-

Table 1: Possible complications after soft tissue fillers injections $(4,7,8)$.

\begin{tabular}{|l|c|}
\hline \multicolumn{1}{|c|}{$\begin{array}{c}\text { TYPE OF COMPLICATION } \\
\text { ACCORDING TO THE TIME OF } \\
\text { OCCURENCE }\end{array}$} & COMPLICATIONS \\
\hline IMMEDIATE & Erythema, edema, pain, bumps, lumps, bruising \\
\hline $\begin{array}{l}\text { EARLY ONSET } \\
\text { (within days) }\end{array}$ & $\begin{array}{r}\text { Infections (most often staphylococcal or streptococcal), non - inflammatory } \\
\text { nodules, hypersensitivity reactions (usually type I), skin discoloration/Tyndal } \\
\text { effect, vascular occlusion and contour irregularities }\end{array}$ \\
\hline $\begin{array}{l}\text { DELAYED } \\
\text { (after weeks or years) }\end{array}$ & $\begin{array}{r}\text { Malar edema, infections (most often mycobacterial or biofilm related), } \\
\text { hypersensitivity reaction (usually type IV), inflammatory nodules, foreign } \\
\text { body granulomatous reactions, migration of implanted material, persistent } \\
\text { discoloration and scarring }\end{array}$ \\
\hline
\end{tabular}


tive tissue stroma. These spaces were surrounded by vacuolated epithelioid histiocytes with a signet-ring like appearance intermixed with few multinucleated giant cells (Fig. 2a, 2b). Although the lesion was reminiscent of liposarcoma, no nuclear atypia was noticed and a foreign body granulomatous reaction was speculated; however polarized light microscopy did not reveal any birefringent material. Before setting a final diagnosis, the patient was contacted and asked if she had been subjected to any aesthetic procedure in the perioral area in the past. At that time, she recalled that she had received hyaluronic acid injections in both nasolabial folds and the lower lip 1.5 year before, however the histopathological features were compatible with silicone, a different filler from the one she thought she had received. The combination of the patient's history and the microscopic examination set the final diagnosis of a FBG to silicone. Nine months after the excisional biopsy, no recurrence has been reported.

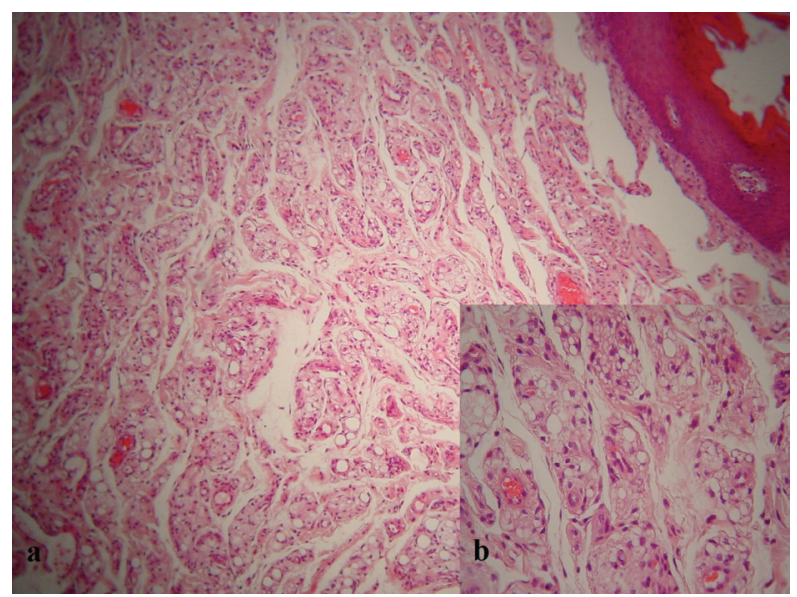

Fig. 2: Multiple clear cystic spaces of varying size intermixed with epithelioid macrophages with vacuolated cystoplasm in a fibrous connective tissue stroma are observed. (a. hematoxylin-eosin stain, original magnification $\mathrm{x} 100, \mathrm{~b}$. hematoxylin-eosin stain, original magnification $\times 200$ ).
Case 2

A 48-year-old, non-smoker, female patient presented to a private oral medicine clinic with an asymptomatic, well-defined submucosal firm nodule on the upper lip, of 4 months duration. Her medical history was non contributory while she had been subjected to hyaluronic acid filler injections in the ipsilateral nasolabial fold six months before her visit to the clinic. On clinical examination, a well - circumscribed submucosal nodule measuring approximately $2 \times 1 \mathrm{~cm}$ was noticed on the left upper lip mucosa. The lesion was covered by normal-appearing mucosa and was painless and soft on palpation (Fig. 3a). The remaining oral mucosa was within normal limits. With a provisional diagnosis of foreign body granuloma and a differential diagnosis of salivary gland and neural tumor, the nodule was excised with no reported recurrence 4 months later. Histopathologically, pools of amorphous, basophilic material compatible with hyaluronic acid that were surrounded by epithelioid macrophages and mild lymphocytic inflammation were observed (Figs. 3b, 3c), confirming the tentative diagnosis of a FBG to hyaluronic acid filler.

\section{Discussion}

The increasing demand for cosmetic procedures in the orofacial area, results in a growing number of complications, including the development of foreign body granulomas (FBGs). FBGs are histopathologically characterized by an organized collection of epithelioid histiocytes, containing foreign body material surrounded by chronic lymphocytic inflammation and fibrosis $(6,12)$. A number of patients and practitioners accept this type of inflammatory lesions as normal as long as there is cosmetic improvement, whereas, from pathologists' perspective, an inflammatory response to foreign material cannot be considered as normal tissue (12).

In addition to the present study, review of the pertinent English literature revealed 104 previously published cases of oral FBGs induced by STFs $(1,3,6,9,11,13-37)$.

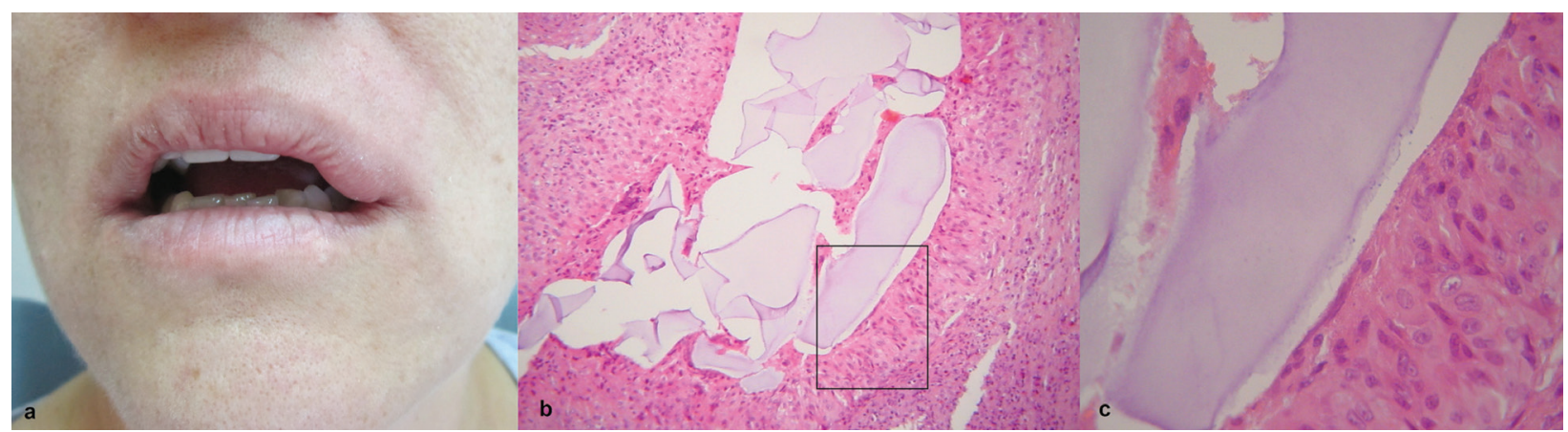

Fig. 3: a. Extraoral view of the submucosal nodule on the upper left labial mucosa in patient 2. A pool of amorphous basophilic material corresponding to hyaluronic acid lined by epithelioid macrophages is observed (b. hematoxylin-eosin stain, original magnification x100, $\mathrm{c}$. hematoxylin-eosin stain, original magnification x200). 
The clinical and demographic data of all reported cases are summarized in Table 2, 2 continue. In all cases, diag- nosis of FBG formation was rendered after histopathological examination. The mean age of the patients was

Table 2: Clinical and demographic data of 104 previously published cases of oral foreign body granulomas induced by injectable soft tissue fillers, plus the 2 cases of the present study.

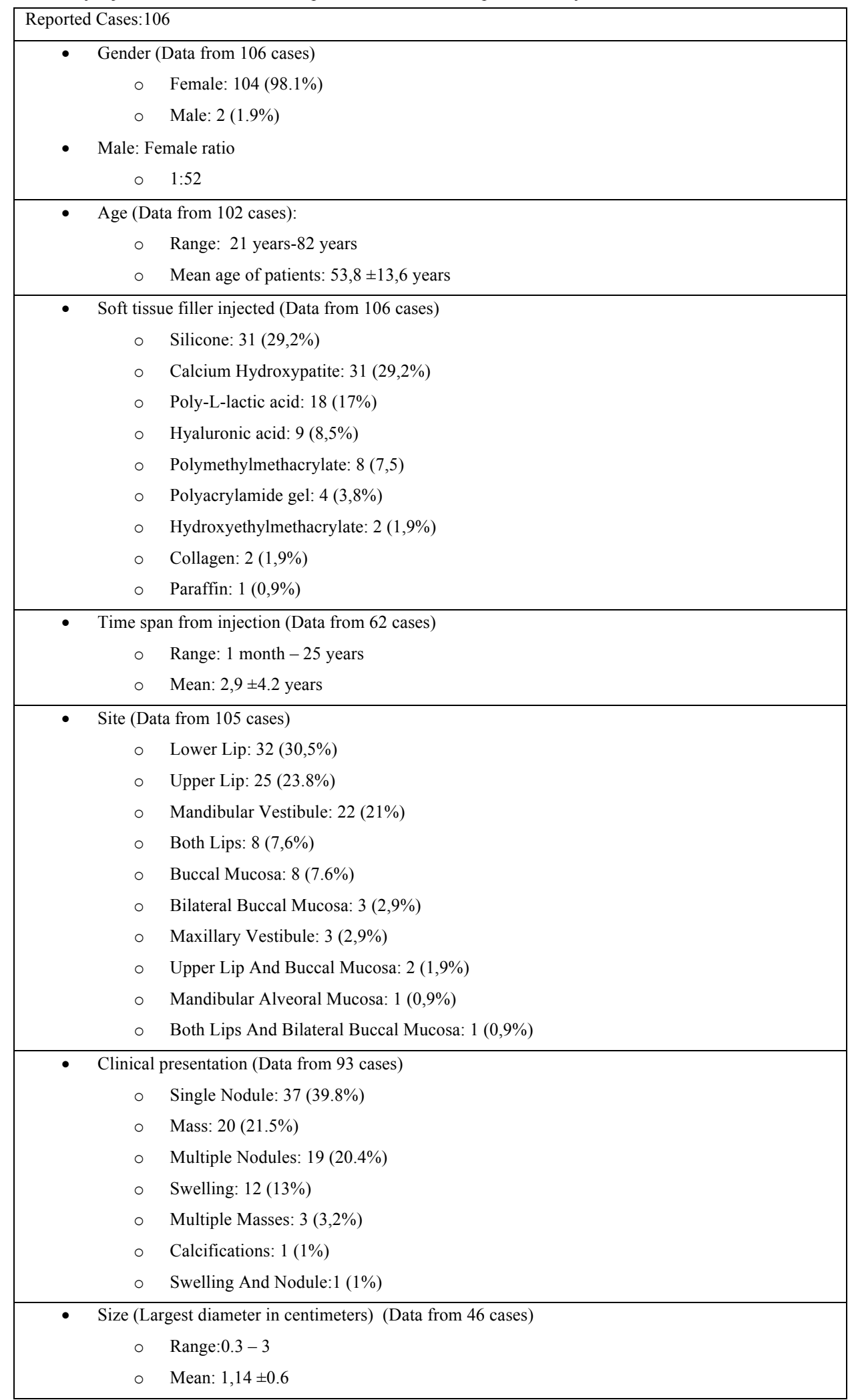


Table 2 continue: Clinical and demographic data of 104 previously published cases of oral foreign body granulomas induced by injectable soft tissue fillers, plus the 2 cases of the present study.

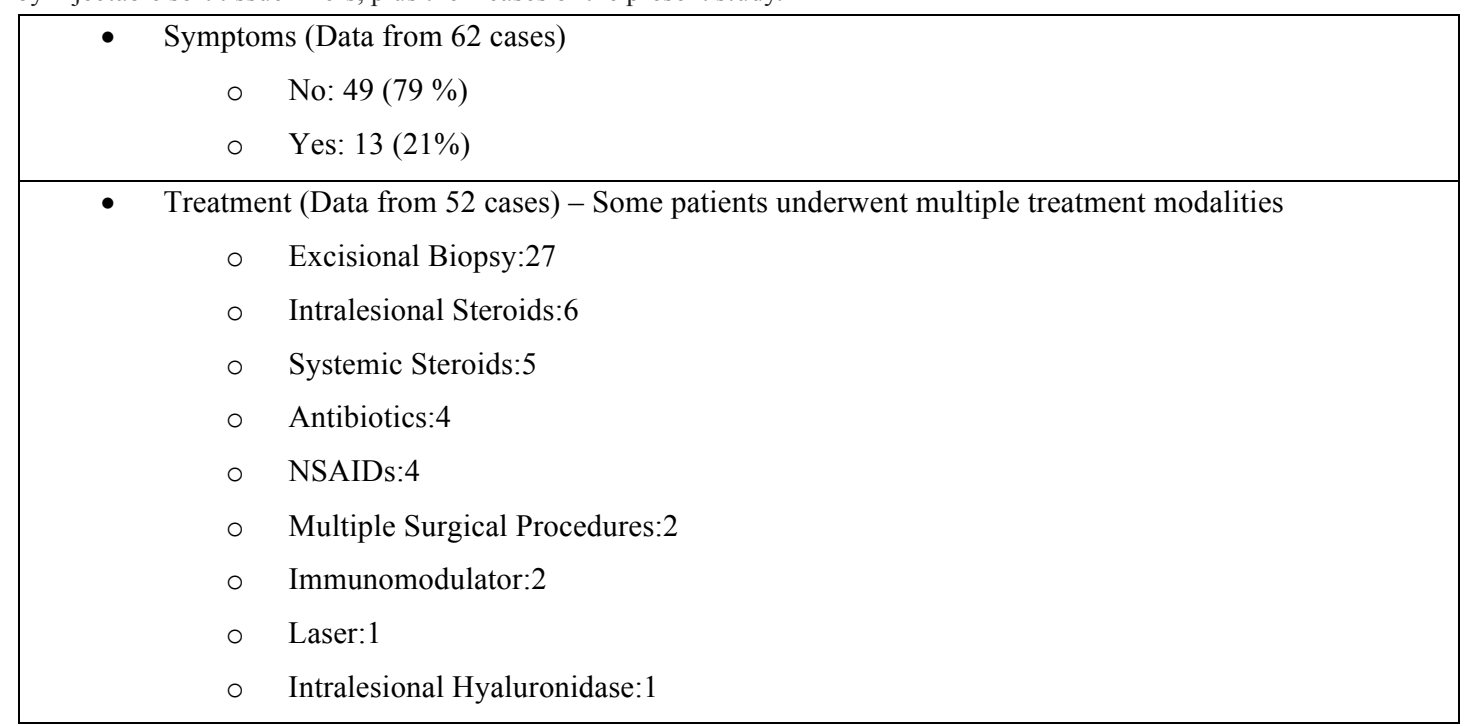

$53,8 \pm 13,6$ years $(1,3,6,9,11,13,15,16,18-35,37)$ while the vast majority $(98,1 \%)$ were women $(1,3,6,9,11,13-$ 37). This strong female predilection obviously reflects the fact that women prefer cosmetic procedures $(6,37)$. The lower lip was the most common location of the lesions $(30,5 \%)(1,3,6,22,24,31,33-36)$ followed by the upper lip $(23,38 \%) \quad(1,6,9,13,14,16,18,26,30,32,34$. Most of the cases were clinically described as single, usually submucosal nodules $(3,6,13,14,16,19,22,24,2$ $6,30,31,33,34,36)$ or masses $(1,3,6,22,23,32,34)$. Concomitant redness or ulceration were scarcely reported whereas the majority of the patients (79\%) reported no symptoms $\quad(6,11,13,14,16,19,21,26,28,29,30,31,33,34$, 36). The differential diagnosis varied depending on the clinical presentation and the location of the lesions. The literature to date shows that in cases which presented as single nodules or masses on the lips the differential diagnosis included mucoceles, benign salivary gland and soft tissue neoplasms, whereas diffuse lip swellings, were differentiated from orofacial granulomatosis, angioedema, Crohn's disease and other less common oral conditions (6). The clinician should suspect a FBG if a patient reports a previous STF injection. Such a reaction may manifest many months or years after the injection (mean 2,9 \pm 4.2 years) $(1,6,9,11,13-19,23-26,29,32,34-$ 37 ) and may even develop in an area distant from the initial injection site (6). However, the diagnosis of a FBG may be challenging for both the clinician and the pathologist when a positive history of STF injection is not disclosed either because there is a long time lapse between the cosmetic procedure and the appearance of the lesion (3), or because the patients purposely conceal the cosmetic procedure for their own reasons(6).

The responsible materials in most cases of FBG were silicone $(3,6,14-16,21,22,27,35,36)$ and calcium hydroxyapatite $(1,3,20,22,26,33,34)$, each one accounting for $29,2 \%$ of cases. FBGs induced by hyaluronic acid $(3,6,18,22,31)$ and collagen $(32,37)$,which are normal components of human and animal tissues, were scarce ( $8,5 \%$ and $1,9 \%$ respectively). In these cases, FBG formation was most probably due to cross-linking and increased concentration (2).

The diagnosis of a granulomatous foreign body reaction is rendered only after microscopic examination. In a single case report, fine needle aspiration cytology was reported as a less invasive method for diagnosis. However, histologic examination was also performed (23). The microscopic identification of the STF type is challenging if a detailed clinical history is not provided, in cases in which more than one filler is injected (37), or if the patient is not aware of the type of material used (3). Rarely, patients report a different type of STF from the one identified histopathologically, probably because the person who performed the injection withheld the true nature of the filler (6) as was the case in the first patient of the present study (case 1).

The histopathological appearance of granulomatous foreign body reactions on hematoxylin and eosin stain seem to be specific for each type of injected filler (3). Therefore, pathologists should be familiar with the characteristic microscopic features of each filler and not necessarily rely on the clinical history (12). Occasionally, two different fillers may be recognized in the same tissue sample, reflecting the injection of two types of fillers in the same patient (26). The histopathological patterns of FBG induced by the different types of STFs are presented in Table 3.

Many factors have been implicated in the etiology of 
Table 3: Histologic patterns of foreign body granulomas to different soft tissue fillers.

\begin{tabular}{|c|c|}
\hline Soft Tissue Filler & Histopathological pattern \\
\hline Silicone & $\begin{array}{l}\text { Clear vacuoles (due to processing) of varying sizes surrounded by } \\
\text { macrophages, interspersed with giant cells and chronic inflammatory cells } \\
(3,22) \text {. Some macrophages have intracytoplasmic vacuoles which vary in size } \\
\text { and number, possibly resulting in a "bubbly" or vesicular appearance (34). } \\
\text { Negative staining for S-100, eliminates the possibility of liposarcoma (34). } \\
\text { Overtime, fibrosis evolves with minimal vacuolar features (22). }\end{array}$ \\
\hline Hyaluronic acid & $\begin{array}{l}\text { Lakes or pools of blue colloidal material surrounded by epithelioid } \\
\text { histiocytes. Positive staining with Alcian Blue at a pH of } 2,5 \text { (3). }\end{array}$ \\
\hline Calcium Hydroxyapatite & $\begin{array}{l}\text { Spherical, uniform sized, brown-grey, grey-green or mauve-grey, fine } \\
\text { granular material measuring } 20-50 \mu \mathrm{m} \text { surrounded by epithelioid histiocytes, } \\
\text { intermixed with multinucleated giant cells and chronic inflammatory cells } \\
(1,3) . \text { There is no significant birefringence under polarization light (1). }\end{array}$ \\
\hline Poly- L- lactic acid & $\begin{array}{l}\text { Pointed, spiky, elongated ('surfboard') vacuoles with ragged edges containing } \\
\text { birefringence refractile material surrounded by multinucleated giant } \\
\text { histiocytes and chronic inflammatory cells (3).The granuloma of } \\
\text { Poly- L- lactic acid may also contain asteroid bodies ( } 34 \text { ). In contrast, } \\
\text { granulomas induced by Hydroxyethylmethacrylate share the same } \\
\text { histopathological pattern but show non- refractile material within the } \\
\text { vacuoles (22). }\end{array}$ \\
\hline Polyacrylamide gel & $\begin{array}{l}\text { Blue clumped material surrounded by a dense chronic inflammatory infiltrate } \\
\text { and multinucleated cells (3). }\end{array}$ \\
\hline Polymethylmethacrylate & $\begin{array}{l}\text { Multiple round cystic spaces of similar size, within or near multinucleated } \\
\text { giant cells in a background of collagen fibrosis with various lymphocytes. The } \\
\text { round spaces contain round, sharply circumscribed, translucent, } \\
\text { non-birefringent in polarized light, foreign bodies (11). }\end{array}$ \\
\hline Collagen & $\begin{array}{l}\text { Collagen surrounded by mononuclear infiltrate containing many } \\
\text { multinucleated histiocytes in a palisaded array (32). }\end{array}$ \\
\hline Paraffin & $\begin{array}{l}\text { Numerous empty (due to processing) cystic spaces of varying size rimmed } \\
\text { by foamy macrophages and multinucleated giant cells. Minimal, thin fibrous } \\
\text { fibers can also be recognized between these spaces. Scattered macrophages, } \\
\text { lymphocytes, mast cells and eosinophilic leukocytes may be present (25). }\end{array}$ \\
\hline
\end{tabular}

FBGs to STFs such as the volume of the injected filler, STF impurities, the surface and the size of the particles (38) or a delayed hypersensitivity reaction (39). However, increasing evidence indicates that granuloma formation may be related to bacterial biofilms $(8,10)$ which adhere to the surface of the filler when the procedure is not performed properly $(9,39,40)$. The bacteria, which are organized in biofilms, are protected from the host immune system, thus remaining in a stable condition (9, 39). Sometime later, ranging from months to years, they may be activated either by another filler injection, dental surgery, infection, trauma or unknown causes $(2,39)$ leading to a host inflammatory response in the form of a granulomatous foreign body reaction $(9,39)$. Polymera- se Chain Reaction and pyrosequencing techniques may also be of help to identify the responsible bacteria (9). Several different treatment approaches have been used $(6,9,11,13,15-21,23-25,28,29,30-33)$ as seen in Table 2. Intralesional steroids represent the first line of treatment; sparing systemic steroids for recurrent lesions, in doses higher than those used before locally (38). The role of antibiotics in FBG treatment is debatable (2). Excision of FBGs should be reserved as the last option, especially when they appear clinically as multiple nodules or as a diffuse swelling, in which case it may be impossible to remove the entire injected material $(10,38)$. However, when FBG presents clinically as a single nodule, as in both of our cases, excisional biopsy is both diagnostic and therapeutic. 


\section{Conclusions}

- Although rare, foreign body granulomas to soft tissue fillers may develop months to several years after the injection. Due to the increasing use of soft tissue fillers, during history taking, the clinician should include questions regarding esthetic procedures performed in the perioral area.

- The pathologist should be familiar with the histologic pattern of each type of filler and not rely solely on the patient's history.

- The treatment of choice for foreign body granulomas is prevention. Clinicians must be highly educated and trained to perform the injections under aseptic conditions, thus minimizing the risk of infection.

\section{References}

1. Daley T, Damm DD, Haden JA, Kolodychak MT. Oral lesions associated with injected hydroxyapatite cosmetic filler. Oral Surg Oral Med Oral Pathol Oral Radiol. 2012;114:107-111.

2. Alijotas-Reig J, Fernández-Figueras MT, Puig L. Inflammatory, immune-mediated adverse reactions related to soft tissue dermal fillers. Semin Arthritis Rheum. 2013;43:241-58.

3. Owosho AA, Bilodeau EA, Vu J, Summersgill KF. Orofacial dermal fillers: foreign body reactions, histopathologic features, and spectrometric studies. Oral Surg Oral Med Oral Pathol Oral Radiol. 2014;117:617-625.

4. El-Khalawany M, Fawzy S, Saied A, Al Said M, Amer A, Eassa B. Dermal filler complications: a clinicopathologic study with a spectrum of histologic reaction patterns. Ann Diagn Pathol. 2015;19:10-15.

5. U.S. Food and Drug Administration. Soft tissue fillers (Dermal fi1lers)[WWW document]2017.URL:https://www.fda.gov/MedicalDevices/ProductsandMedicalProcedures/CosmeticDevices/WrinkleFi1lers/ucm2007470.html

6. Jham BC, Nikitakis NG, Scheper MA, Papadimitriou JC, Levy BA, Rivera $\mathrm{H}$. Granulomatous foreign-body reaction involving oral and perioral tissues after injection of biomaterials: a series of 7 cases and review of the literature. J Oral Maxillofac Surg. 2009;67:280-5.

7. Haneke E. Adverse effects of fillers and their histopathology. Facial Plast Surg. 2014;30:599-614.

8. Chiang YZ, Pierone G, Al-Niaimi F. Dermal fillers: pathophysiology, prevention and treatment of complications. J Eur Acad Dermatol Venereol. 2017;31:405-413.

9. Kunjur J, Witherow H. Long-term complications associated with permanent dermal fillers. Br J Oral Maxillofac Surg. 2013;51:858-862. 10. Wagner RD, Fakhro A, Cox JA, Izaddoost SA. Etiology, Prevention, and Management of Infectious Complications of Dermal Fillers. Semin Plast Surg. 2016;30:83-86.

11. Quirino MR,Neves AC, Campos MS, Brandão AA, Anbinder AL. Oral granuloma formation after injection of cosmetic filler. J Craniomaxillofac Surg. 2012;40:e194-7.

12. Daley T, Damm DD. Oral lesions associated with injected hydroxyapatite cosmetic filler- reply. Oral Surg Oral Med Oral Pathol Oral Radiol. 2013;115:419-20.

13. Akrish S, Dayan D, Taicher S, Adam I, Nagler RM. Foreign body granulomas after injection of Bio-alcamid for lip augmentation. Am J Otolaryngol. 2009;30:356-9.

14. Álvarez-Garrido H, Pericet-Fernández L, Martínez-García G, Tejerina-García JA, Peral-Martínez I, Miranda-Romero A. Crohn's disease and cheilitis granulomatosa: role of silicone fillers. J Am Acad Dermatol. 2011;65:239-41.

15. Anastassov GE, Schulhof S, Lumerman H. Complications after facial contour augmentation with injectable silicone. Diagnosis and treatment. Report of a severe case. Int J Oral Maxillofac Surg. 2008;37:955-60.
16. Bisschop C, Bruijn MS, Stenekes MW, Diercks GF, Hospers GA. Foreign body reaction triggered by cytotoxic $\mathrm{T}$ lymphocyte-associated protein 4 blockade 25 years after dermal filler injection. Br J Dermatol. 2016; 175:1351-1353.

17. Costa FW, Teixeira LH, Carvalho FS, Chaves FN, Turatti E, Ribeiro TR, Pereira KM. Bilateral oral nodules after the use of a dermal filler containing polymethylmethacrylate microspheres in an older woman. J Am Geriatr Soc. 2014;62:587-8.

18. Curi MM, Cardoso CL, Curra C, Koga D, Benini MB. Late-onset adverse reactions related to hyaluronic Acid dermal filler for aesthetic soft tissue augmentation. J Craniofac Surg. 2015;26:782-4.

19. da Costa Miguel MC, Nonaka CF, dos Santos JN, Germano AR, de Souza LB. Oral foreign body granuloma: unusual presentation of a rare adverse reaction to permanent injectable cosmetic filler. Int J Oral Maxillofac Surg. 2009;38:385-7.

20. Dammak A, Taillé C, Marinho E, Crestani B, Crickx B, Descamps V. Granulomatous foreign-body reaction with facial dermal fillers after omalizumab treatment for severe persistent allergic asthma: a case report. Br J Dermatol. 2012;166:1375-6.

21. Ellis LZ, Cohen JL, High W. Granulomatous reaction to silicone injection. J Clin Aesthet Dermatol. 2012;5:44-7.

22. Eversole R, Tran K, Hansen D, Campbell J. Lip augmentation dermal filler reactions, histopathologic features. Head Neck Pathol. 2013;7:241-9.

23. Faria KM, Fonseca FP, Silva WG, Silva RN, Vargas PA, de Almeida OP, Lopes MA, Santos-Silva AR. Fine needle aspiration cytology in the diagnosis of perioral adverse reactions to cosmetic dermal fillers. Oral Surg Oral Med Oral Pathol Oral Radiol. 2014;117:e393-5.

24. Feio PS, Gouvêa AF, Jorge J, Lopes MA. Oral adverse reactions after injection of cosmetic fillers: report of three cases. Int J Oral Maxi1lofac Surg. 2013;42:432-5.

25. Friedrich RE, Zustin J. Paraffinoma of lips and oral mucosa: Case report and brief review of the literature. GMS Interdiscip Plast Reconstr Surg DGPW 2014 May 15;3:Doc05.

26. Goulart JM, High WA, Goldenberg G. Evidence of calcium hydroxylapatite migration: distant nodule formation in the setting of concurrent injection with nonanimal stabilized hyaluronic acid. J Am Acad Dermatol. 2011;65:e65-6.

27. Grippaudo FR, Di Girolamo M, Mattei M, Pucci E, Grippaudo C. Diagnosis and management of dermal filler complications in the perioral region. J Cosmet Laser Ther. 2014;16:246-52.

28. Karagozoglu KH, van der Waal I. Polyacrylamide soft tissue filler nodule mimicking a mucoepidermoid carcinoma. Int J Oral Maxillofac Surg. 2008;37:578-80.

29. Kawamura JY, Domaneschi C, Migliari DA, Sousa SO. Foreign body reaction due to skin filler: a case report. Oral Surg Oral Med Oral Pathol Oral Radiol Endod. 2006;101:469-71.

30. Lee JJ, Wang YP, Wu YH, Chang JYF. Poly-1-lactic acid injection-induced delayed-onset foreign body granuloma. J Formos Med Assoc. 2017;116:402-403.

31. Tseng CH, Wang YP, Chen HM, Chang JYF. Hyaluronic acid injection-induced delayed-onset foreign body granuloma. J Dent Sci. 2015;10:341e3.

32. Moscona RR, Bergman R, Friedman-Birnbaum R. An unusual late reaction to Zyderm I injections: a challenge for treatment. Plast Reconstr Surg. 1993;92:331-4.

33. Sankar V, McGuff HS. Foreign body reaction to calcium hydroxylapatite after lip augmentation. J Am Dent Assoc. 2007;138:1093-6.

34. Shahrabi-Farahani S, Lerman MA, Noonan V, Kabani S, Woo $\mathrm{SB}$. Granulomatous foreign body reaction to dermal cosmetic fillers with intraoral migration. Oral Surg Oral Med Oral Pathol Oral Radiol. 2014;117:105-10.

35. Waller JM, Wu JJ, Murase JE, Dyson SW. An indurated, enlarged lower lip. Clin Exp Dermatol. 2008;33:799-800.

36. Wang T, Raphael S, Klieb H. Swelling affecting the left inferior labial mucosa. Granulomatous reaction to cosmetic lip injection. JAMA Otolaryngol Head Neck Surg. 2014; 140:271-2.

37. Sanchis-Bielsa JM, Bagán JV, Poveda R, Salvador I. Foreign body 
granulomatous reactions to cosmetic fillers: a clinical study of 15 cases. Oral Surg Oral Med Oral Pathol Oral Radiol Endod. 2009;108:237-41.

38. Lee JM, Kim YJ. Foreign body granulomas after the use of dermal fillers: pathophysiology, clinical appearance, histologic features, and treatment. Arch Plast Surg. 2015;42:232-9.

39. Florin W, Mandel L. Foreign body reaction to facial dermal fillers: case report. J Oral Maxillofac Surg. 2012;70:2352-5.

40. Constantine RS, Constantine FC, Rohrich RJ. The ever-changing role of biofilms in plastic surgery. Plast Reconstr Surg. 2014;133:865e-872e

\section{Conflicts of Interest}

The authors have declared that no conflict of interest exist. 